Apidologie, 1976, 7 (1), 67-84.

\title{
PYRIDOXINE REQUIREMENT OF THE HONEY BEE (APIS MELLIFERA) FOR BROOD REARING
}

\author{
Leroy M. ANDERSON and A. DIETZ \\ Department of Entomology \\ University of Georgia \\ Athens, Georgia 30602 \\ U.S.A.
}

\section{SUMMARY}

The aim of the present study was to determine the quantitative requirement of the $B$ vitamin pyridoxine for brood rearing activities of caged honey bees. The diets were tested with small colonies of bees maintained in large flight cages.

The findings support the work done by previous investigators reporting that pyridoxine is required in the diet of honey bee larvae. Diet $D$ which contained $4 \mathrm{mg}$ per 500 grams of artificial diet is adequate for larval development. The average daily food intake of adult bees fed diet $\mathrm{D}$ was $4.9 \mathrm{mg} / \mathrm{bee}$. To rear one larva to the sealed brood stage, $670 \mathrm{mg}$ of diet $\mathrm{D}$ which contained $134 \mathrm{mg}$ of casein and $5.4 \mu \mathrm{g}$ of pyridoxine were consumed by an average of 1085 caged adult bees.

This investigation also shows that the proper diet preparation is of utmost importance when rearing bees in confinement. The diet must not only be mixed thoroughly to insure distribution of all diet components, but also contain a sufficient amount of moisture to facilitate proper consumption. The consistency of the diet and the amount of sugar syrup available to the bees determines the amount of diet the bees consume, which, in turn, influences the number of larvae that can be reared. The diet intake is a direct indication of the amount of vitamins and other micronutrients being ingested by the bees.

\section{INTRODUCTION}

The importance of an adequate supply of pollen to produce strong populations of honey bees (Apis mellifera) is generally recognized. Studies by HAYDAK (1935) showed that weight and nitrogen content of emerging bees is directly influenced by the pollen consumption of the nurse bees and the fluctuation in the pollen income of the colony. Growth begins as soon as newly emerged bees start feeding on pollen, with a resultant increase in longevity, development of their brood food glands, fat bodies and other organs (Ma urizio, 
1954). Newly emerged bees need pollen for the preparation of larval food (HAYDAK, 1961 a).

It has been shown (DE Groot, 1953; Maurizio, 1954) that for normal growth of young adult honey bees, and for the development of their hypopharyngeal glands, only a protein source is required, preferably one with adequate amounts of L-arginine and L-lysine (DIETz and HAYDAK, 1965). However, it has also been demonstrated that vitamins of the $B$ group are necessary for normal brood rearing of honey bees (HAYDAK, 1949; WAHL and BACK, 1955; BACK, 1956; HaydaK and Dietz, 1965, 1972). The abundance of water soluble $B$ vitamins found in the larval food of bees is derived from pollen (Aeppler, 1922; Dutcher, 1918; Koch and Schwarz, 1956).

There is massive evidence that seven $B$ complex vitamins, thiamine, riboflavin, nicotinamide, pyridoxine, pantothenate, folic acid and biotin, are essential for insects in general (DADD, 1973). These vitamins must be supplied in the proper balance with the other nutrients. In his studies with Drosophila melanogaster Meigen, SANG (1962) showed that the vitamin requirements were related to the dietary protein level.

Newly emerged bees carry over a store of vitamins from their larval stage and have no apparent need of additional vitamins except for brood rearing (BACK, 1956). The "fat body" of the abdomen serves as the general reserve tissue (HAYDAK and Vivino, 1943). Bees can use their stored protein reserves for the production of larval food (HAYDAK, 1949), making it possible for adults to rear brood for a relatively short period of time when fed only a pure carbohydrate diet, as shown by HAYDAK in 1935 . When fed an artificial diet which contained vitamin-free casein, honey bees reared brood initially, but could not continue it (BACK, 1956).

Kitzes et al. (1943) reported that there was $10.2 \mu \mathrm{g}$ per $\mathrm{g}$ of pyridoxine in royal jelly as compared to the finding by HAYDAK (1960) that royal jelly contained $20.34 \mu \mathrm{g}$ per g. The relatively high pyridoxine concentration found in the tissue of young larvae of all three castes decreases during larval development (HANSER, 1971). She also indicated that there is a seasonally dependent change in the pyridoxine values of worker jelly. Pyridoxine increases from a fresh weight of $3.87 \mu \mathrm{g}$ per $\mathrm{g}$ in May to a fresh weight of $8.49 \mu \mathrm{g}$ per $\mathrm{g}$ in July and August.

The biochemical function of pyridoxine has been studied in rice moth larvae (Corcyra cephalonica St.), and vitamin $B_{6}$ plays a role in tryptophan metabolism. The site of action of pyridoxine is in between 3-hydroxykynurenine and 3-hydroxyanthranilic acid (Sundaram and Sarma, 1953). Pyridoxine has been shown to be essential for the function of kynureninase, an enzyme which removes the side chains from kynurenine and hydroxykynurenine (Dalgliesh, 1951). Pyridoxal phosphate was reported by Pinamonti 
et al. (1970) to be necessary for the activity of the enzyme kynurenine transaminase in the locust. However, the site of the biochemical action of pyridoxine in the honey bee has not yet been determined.

Many insects can be reared in the laboratory using artificial diets. Larval Megachile rotundata are not dependent on pollen, because their nutritional requirement can be met by a broad range of pollens or by an artificial diet (Nelson et al., 1972). Haydak and Dietz (1965) and Weaver (1964) developed diets which honey bees utilized to rear brood to maturity. However, they were inferior to pollen since the amount of brood that the nurse bees reared was limited.

The larval requirement of honey bees for vitamins can be judged only from inference (HAYDAK, 1970). By using an artificial diet, it was shown that honey bees require pyridoxine for brood rearing (HAYDAK and DiETz, 1972). The present investigation was conducted to establish the quantitative requirement of the $B$ vitamin pyridoxine for larval development in honey bees.

\section{MATERIAL AND METHODS}

\section{Cages}

The bees were kept in small hives or nuclei which had the following dimensions : $15 \times$ $20 \times 25 \mathrm{~cm}$. The nuclei could be opened from the top and one side. The bottom and two ends were wooden, and the top and the sides were covered with nylon screen.

Combs utilized in this experiment were freshly drawn out in the spring; they did not contain any pollen and no brood had been reared in them. Three combs were cut to fit the small wooden frames which were placed in each nucleus. The nuclei were placed inside larger flight cages with the following dimensions $(35 \times 107 \times 132 \mathrm{~cm})$. The flight cages were kept in two adjoining rooms, and the air in the rooms was circulated by a fan located in the doorway. A heater, also placed in the doorway, kept the temperature at $29 \pm 1^{\circ} \mathrm{C}$, which was checked by thermometers placed at various locations in the two rooms. The windows were covered to keep out sunlight.

\section{Bees}

Italian workers and queens (Apis mellifera ligustica Spin.) were used in the experimental work. Combs of emerging brood were taken from newly established package colonies and transferred to a laboratory incubator maintained at a temperature of $35{ }^{\circ} \mathrm{C}$. To prevent food ingestion, the brood combs were removed every two hours (DIETz, 1969), and the newly emerged worker bees brushed into a plastic container, weighed and then introduced into the nuclei. Bees were added continuously to the nuclei until each had approximately 300 grams of bees. Tested queens were subsequently released into each nucleus.

Four days after the start of the experiment, water was supplied ad libitum to the bees in each nucleus. One week after the nuclei had received their full weight of bees, they were allowed to fly inside the larger flight cages. At this time, the dead bees and diet remnants were removed from the bottom boards of the nuclei and recorded.

At the beginning of the experiment the colonies were examined every few days to ascertain when egg laying was initiated in order to determine when the first day of sealed brood occurred. Thereafter brood counts were made at 10-day intervals. The queens in all cages, except cage 11 , were laying eggs throughout the experiment. The queen in cage 11 laid eggs 
until day 24. However, the pyridoxine-deprived nurse bees could not successfully rear any larvae to the sealed brood stage, nor provide the queen subsequently with food adequate enough for egg-laying. During the entire experiment, the brood combs were examined and no cannabalism of larvae or pupae was observed. No brood or adult bee diseases were evident.

\section{Diets}

The diets were formulated according to the procedure described by HAYDAK and DIETZ (1972). All vitamins (except ascorbic acid) were dissolved in $10 \mathrm{ml}$ of distilled water and added to the other diet components. Ascorbic acid was directly added to the diets. The casein, invert sugar, Wesson salt mixture, vitamins and cholesterol used in the test diets were obtained from Nutritional Biochemicals Corporation, Cleveland, Ohio. Dixie Crystals powdered sugar also was used in the diets. Six diets, differing only in the amount of pyridoxine added (Table 1), were tested in the experiment : Diet $A$-ages 1 and 2, Diet $B$ - cages 3 and 4, Diet $C$-cages 5 and 6, Diet $D$-cages 7 and 8 , Diet E-cages 9 and 10 and Diet F-cages 11 and 12 .

TAB. 1. - Composition of the artificial candy diet

for rearing successive generations of honey bees

\begin{tabular}{|c|c|}
\hline Components & $g$ \\
\hline $\begin{array}{l}\text { Powdered sugar } \\
\text { Invert sugar } \\
\text { Casein (vitamin-free) } \\
\text { Wesson salt mixture } \\
\text { Cholesterol } \\
\text { Ascorbic acid } \\
\text { Vitamins } \\
\text { Choline chloride } \\
\text { Niacin } \\
\text { Calcium panthothenate } \\
\text { Thiamine hydrochloride } \\
\text { Riboflavin } \\
\text { Pyridoxine hydrochloride } \\
\text { Folic acid } \\
\text { Biotin } \\
\text { Inositol } \\
\text { Vitamin } B_{12}\end{array}$ & $\begin{array}{c}250 \\
150 \\
100 \\
3.5 \\
0.2 \\
(m g) \\
5000 \\
1000 \\
360 \\
40 \\
18 \\
36 \\
0.0-10 \\
5 \\
0.5 \\
360 \\
0.04\end{array}$ \\
\hline
\end{tabular}
diets.

* Only invert sugar (400 g) was used in the initial paste

** Amounts of vitamins present in vitamin-free casein $(\mu \mathrm{g} / \mathrm{g})$ : Biotin-.0012; Folic acid-.29; Niacin-.30; Pantothenic acid-.15; Pyridoxine hydrochloride-.63: Riboflavin.50 ; Thiamine hydrochloride-.14; Vitamin $\mathrm{B}_{12}-.003$.

*** Concentration of pyridoxine $(\mathrm{mg})$ present in the different diets : A-10; B-8; C-6; D-4; E-2; F-0.

At the start of the study, the paste diets were poured into the cells of the combs. Throughout the rest of the experiment, the diets were given to the bees as a solid candy placed in inverted plastic petri dishes on the top bars of the combs. The candy diets contained the same amount of casein, salt, cholesterol, and vitamin mixtures as the paste form, but in addition contained powdered sugar and differed in the amount of invert sugar. The ratio of powdered sugar and invert sugar was changed because the candy diets at first were too hard to be consumed properly. By adding more invert sugar to replace powdered sugar, the consistency of the diet was improved without a change in the protein or vitamin content. 
A fresh jar of water was given to the bees every day during the experiment. Sugar syrup was given to the bees every day at the beginning of the experiment, but later it was supplied only occasionally. This change was made when it was discovered that the bees showed a preference for the sugar syrup instead of their test diets.

At the conclusion of the investigation, the accumulated data were analyzed using the M.U.D.A.I.A. (Multivariant, univariant and discriminant analyses of irregular data) program of the C.D. 6400 computer and the L.S.D. (Least significant difference) test.

\section{RESULTS}

The daily food consumption of bees which fed on the six different test diets is shown in Figures 1 and 2. In all cages, the diet consumption declined until a low point was reached (day 19). The food consumption subsequently increased as evidenced by additional peaks (Figures 1 and 2). Another drop was experienced at day 33 which was followed by an increase in food intake during the 33- to 50-day period. A considerably smaller drop in food intake occurred during the 51- to 70-day period. The irregular food consumption patterns are the direct result of providing the caged honey bees with sugar syrup. In this situation, bees preferred the sugar syrup over the test diets.

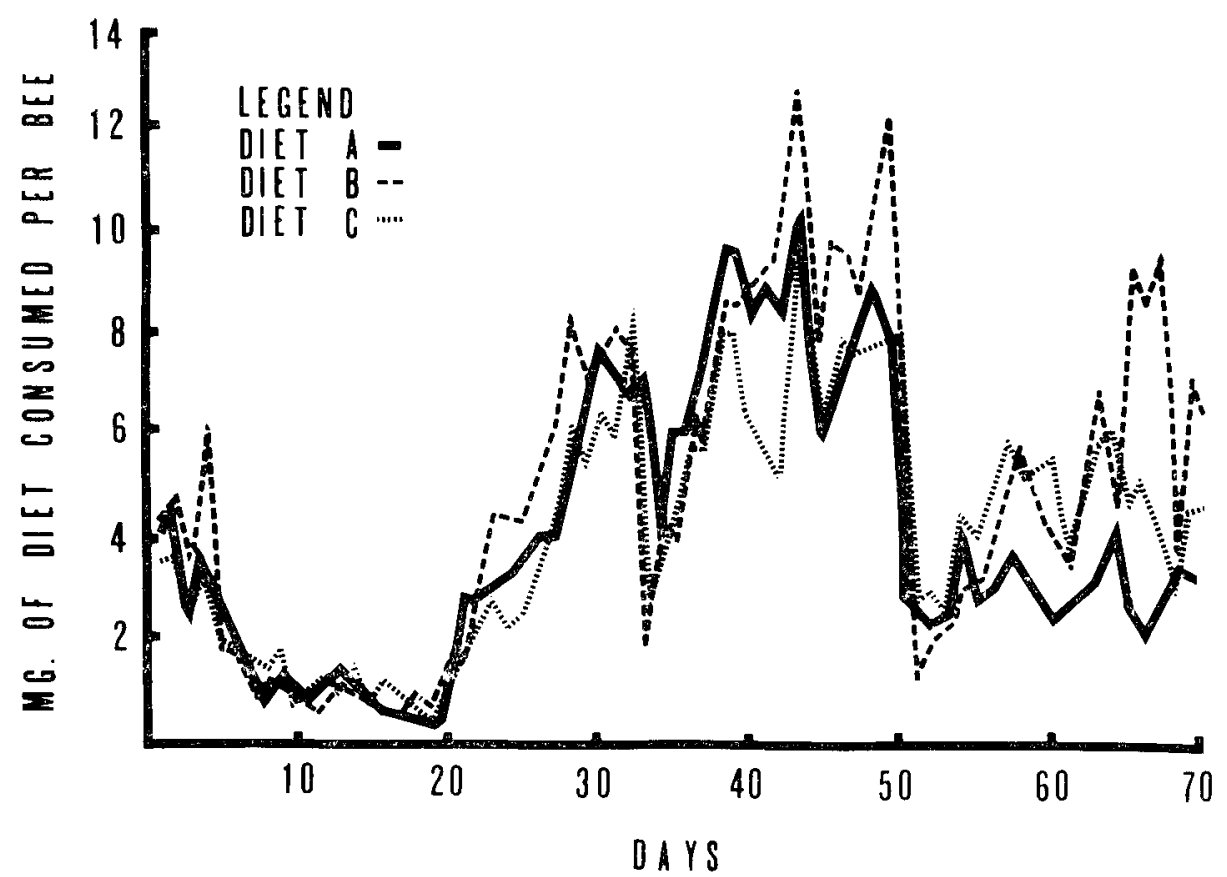

FIG. 1. - Daily food consumption of diets $A, B$ and $C$ by caged honey bees. 


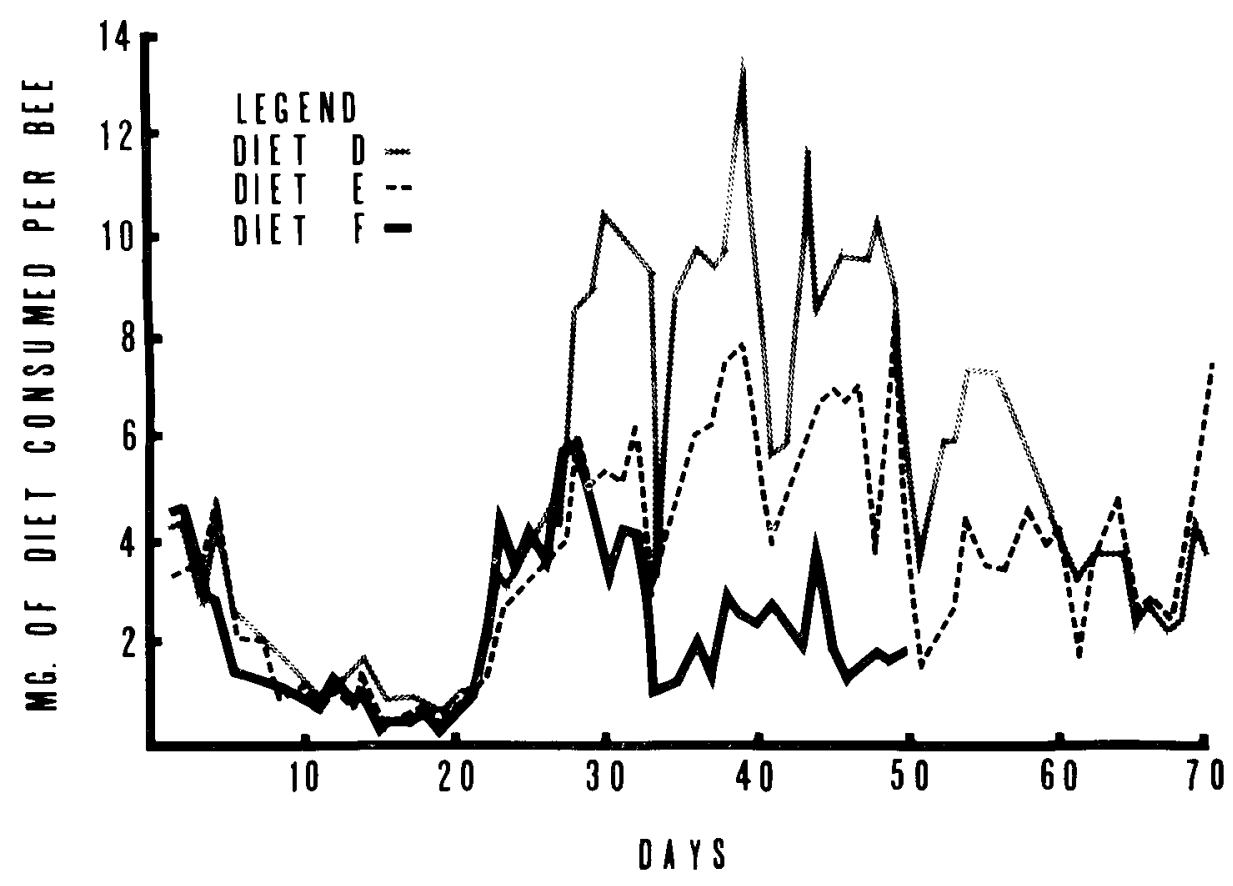

FIG. 2. - Daily food consumption of diets D, E and F by caged honey bees.

Five brood counts, including two preliminary ones, were made at 10 -day intervals. The total numbers of both the sealed brood cells and the open larvae were determined (Table 2). By counting the live bees at the conclusion of the experiment, the percentage of survival was established (Table 2) on the basis of 8 newly emerged bees per gram. The number of bees emerging from the sealed cells was added to the total number of bees in the cages. The amount of diet and pyridoxine used to rear one larva to the sealed brood stage is given in Table 3 . Table 3 also shows the average number of adult bees present in each cage. The average daily food intake of an individual bee during the 70-day test period is shown in Table 4. The various diets were evaluated by comparing the amount of food consumed by the caged bees with the number of larvae reared to the sealed brood stage (Table 5). Data were obtained from three 10-day intervals (days 21-30,31-40 and 41-50), which are referred to as brood count periods (I, II and III) respectively.

When all diets are combined, bees reared an average of 1.19 larvae per gram of food consumed during the 2 nd brood count period (Table 5). This was not significantly different at the $10 \%$ level from the 3 rd brood count 


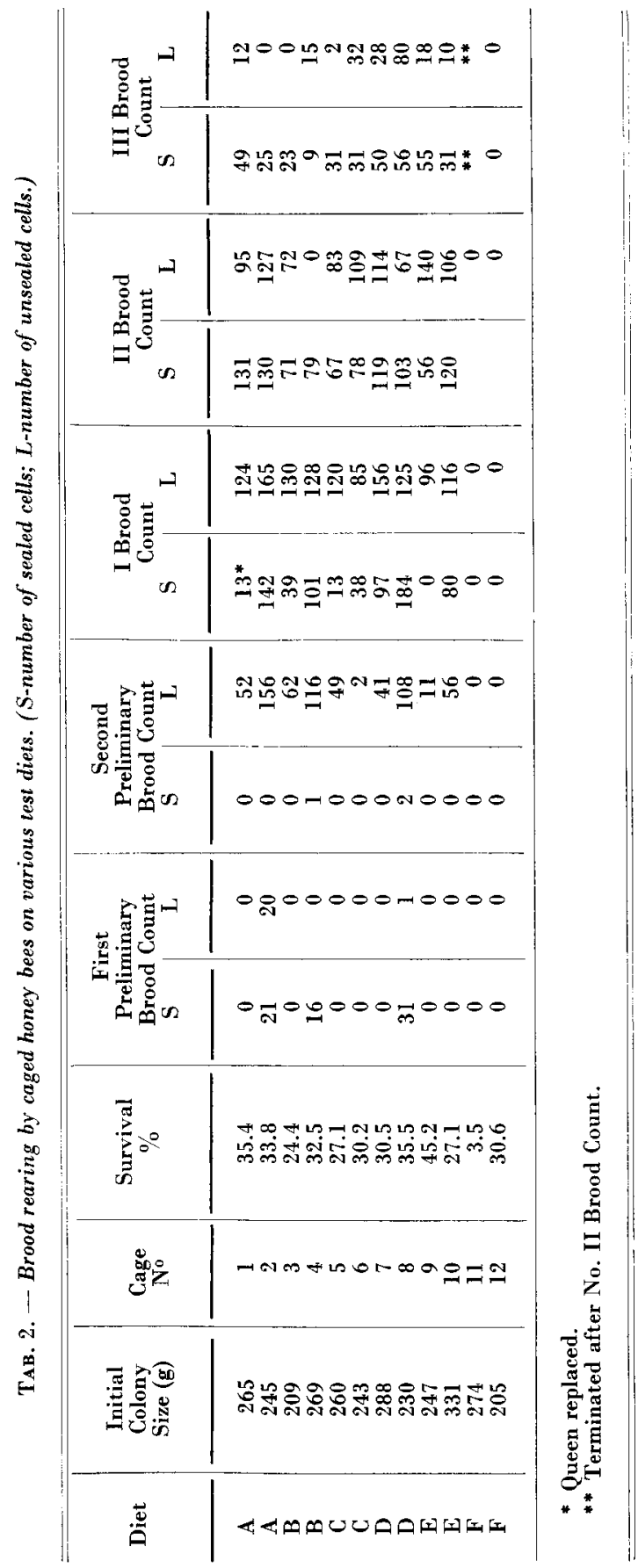


L. M. ANDERSON, A. DIETZ

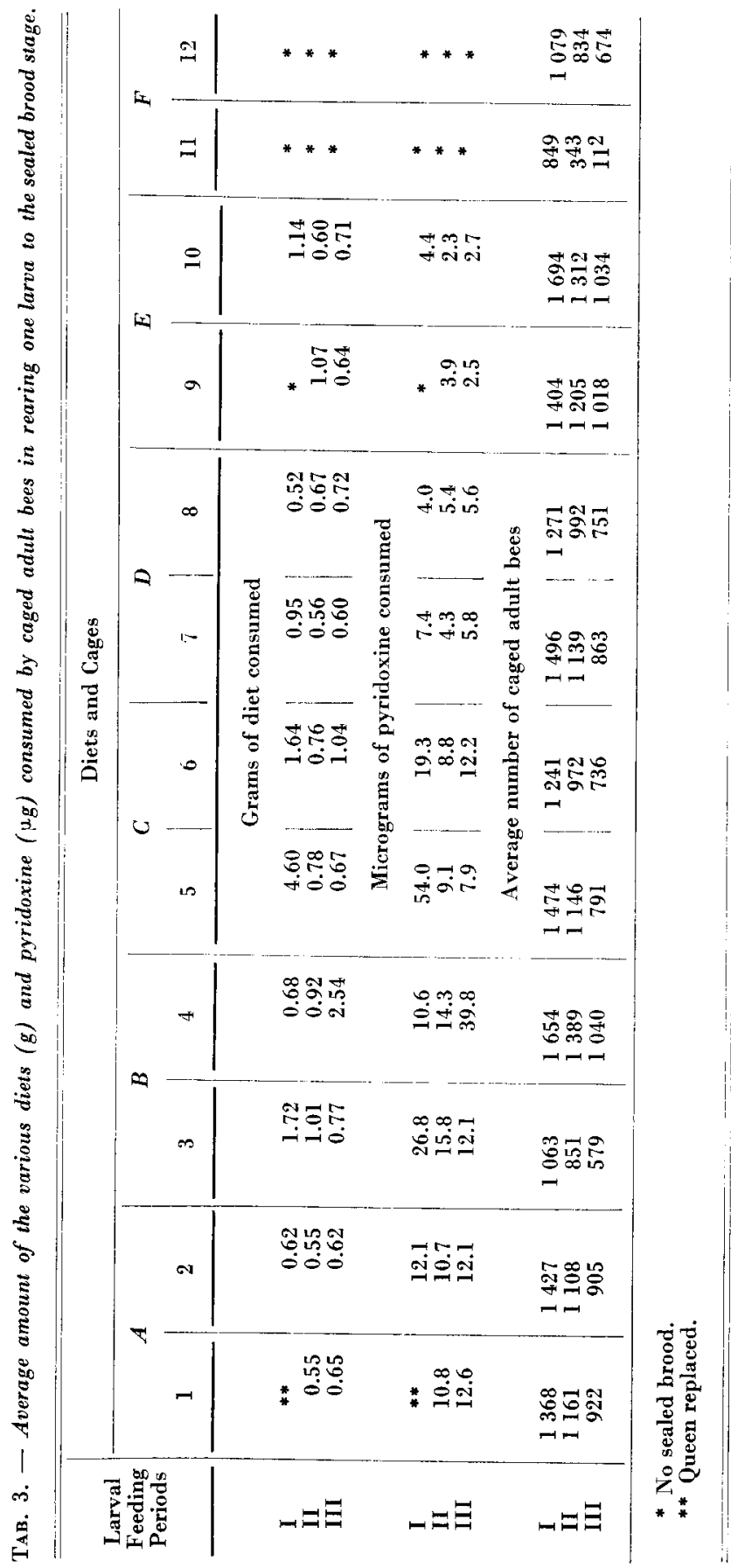


TABL. 4. - Average daily food intake of an individual bee on various test diets

\begin{tabular}{|c|c|c|c|c|c|c|}
\hline \multirow{2}{*}{ Days } & \multicolumn{6}{|c|}{ Diet Consumption (mg) } \\
\hline & Diet A & Diet B & Diet C & Diet D & Diet E & Diet $F$ \\
\hline $\begin{array}{r}1-10 \\
11-20 \\
21-30 \\
31-40 \\
41-50 \\
51-60 \\
61-70\end{array}$ & $\begin{array}{l}4.0 \\
1.5 \\
4.4 \\
7.2 \\
7.8 \\
3.0 \\
3.1\end{array}$ & $\begin{array}{l}2.6 \\
0.8 \\
5.3 \\
6.5 \\
9.7 \\
3.5 \\
6.5\end{array}$ & $\begin{array}{l}2.3 \\
0.9 \\
3.6 \\
5.8 \\
7.5 \\
4.4 \\
4.6\end{array}$ & $\begin{array}{l}2.7 \\
1.1 \\
5.0 \\
8.1 \\
8.7 \\
5.5 \\
3.2\end{array}$ & $\begin{array}{l}2.5 \\
0.7 \\
3.5 \\
5.8 \\
6.1 \\
3.4 \\
3.8\end{array}$ & $\begin{array}{c}2.1 \\
0.6 \\
3.7 \\
2.2 \\
2.0 \\
* \\
*\end{array}$ \\
\hline Average & 4.4 & 5.0 & 4.2 & 4.9 & 3.7 & 2.1 \\
\hline
\end{tabular}

* No test.

TABL. 5. - Average number of larvae reared to the sealed brood stage for each gram of diet consumed by caged adult bees

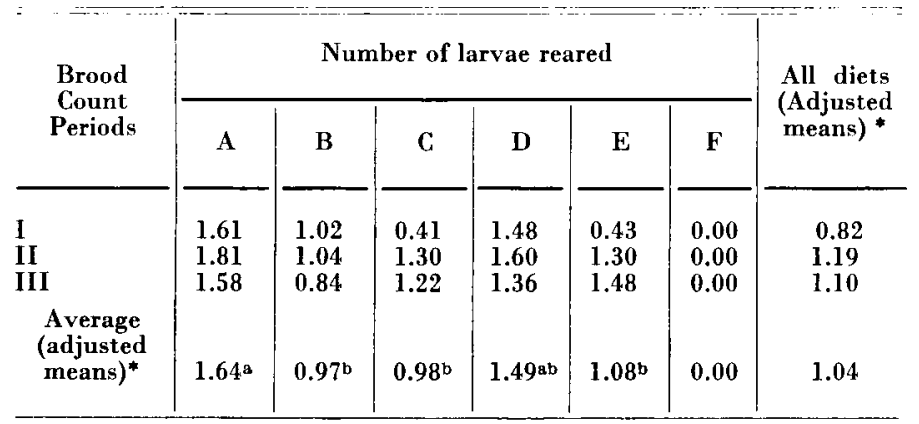

* Computer adjusted means.

any 2 means followed by the same letter are not significantly different at the $5 \%$ level. 
period in which one gram of food consumed resulted in the rearing of 1.10 larvae. Both the 2 nd and 3 rd periods differed from the 1 st one in which only 0.82 larvae per gram of food consumed were produced. In comparing the six diets, there was no statistical difference at 0.05 level of significance between diets $\mathrm{A}$ (1.64 larvae) and $\mathrm{D}$ (1.49 larvae) or between diets D, E (1.08 larvae), C (0.98 larvae) and B (0.97 larvae) during the brood count periods I, II and III (Table 5). The bees which fed on diet $F$ (no pyridoxine) failed to rear any larvae to the sealed brood stage.

When the different periods were evaluated by comparing the number of sealed cells produced by an individual adult bee (Table 6), period II (.10) had the highest ratio followed by period I $(0.06)$ and period III $(0.04)$. The bees reared 0.12 larvae on diet $\mathrm{D}, 0.10$ larvae on diet $\mathrm{A}$ and 0.07 larvae on diet $B$. The nurse bees feeding on diets $C$ and $E$ reared 0.06 larvae to the sealed brood stage per bee. Bees on diet $F$ failed to produce brood.

TABL. 6. - Average number of larvae reared to the sealed brood stage by an individual bee

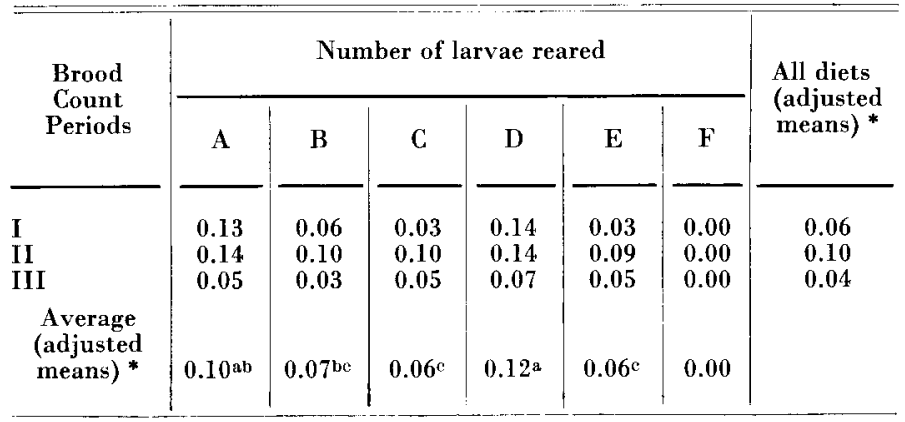

* Computer adjusted means.

any 2 means followed by the same letter are not significantly different at the $5 \%$ level.

Table 7 shows that the bees in all cages consumed more diet per bee during the $2 \mathrm{nd}$ brood rearing period $(71.2 \mathrm{mg})$, followed by the 1 st $(62.2 \mathrm{mg})$ then the $3 \mathrm{rd}(33.8 \mathrm{mg})$. The adult bees which fed on diet $\mathrm{D}$ consumed the greatest average amount of food per bee $(77.2 \mathrm{mg})$ followed by diets $\mathrm{B}(65.9 \mathrm{mg})$, A $(61.4 \mathrm{mg}), \mathrm{C}(58.7 \mathrm{mg}), \mathrm{E}(52.5 \mathrm{mg})$ and $\mathrm{F}(15.4 \mathrm{mg})$. At 0.05 level of significance, there were statistical differences between diets $\mathrm{D}, \mathrm{E}$ and $\mathrm{F}$ (Table 7). 
TABL. 7. - Average amount of the various diets consumed per adult bee during three brood count periods

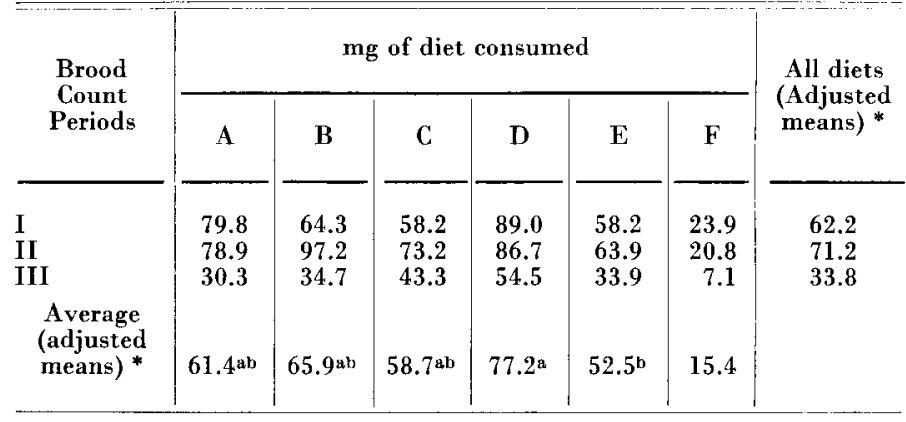

* Computer adjusted means.

a Any 2 means followed by the same letter are not significantly different at the $5 \%$ level.

\section{DISCUSSION}

The varying concentrations of pyridoxine in $\operatorname{diets} A, B, C, D$ and $E$ did not appreciably affect the number of larvae which could be reared to the sealed brood stages. Diet A was formulated by the identical procedures used by HAYDAK and DIETz (1972) in making up their control diet in which five cycles of brood were reared. Diets $(A, B, C, D$ and $E)$ varied only in the amount of pyridoxine (Table 1). However, the bees which fed on $\operatorname{diet} F$ (no pyridoxine) could not rear brood to the sealed stage. This finding is in agreement with the report by HAYDAK and Dietz (1972). The bees used in their experiments likewise failed to rear brood continuously to the adult stage when they were fed on an artificial diet containing no pyridoxine.

In some cases, insects rely on symbiotic microorganisms to supply the necessary vitamins. Jurzitza (1969) reported that normal Lasioderma serricome (Coleoptera : Anobiidae) were reared on a totally synthetic vitamin-free diet for four successive generations. Although development was substantially retarded when it was compared with that of a diet containing all $B$ vitamins and a sterol necessary for growth of aposymbiotic larvae. Microorganisms are able to supply certain vitamins for insects that are reared on an artificial diet which does not contain symbionts. However, this is apparently not the case with caged honey bees. Gilliam (1971) reported that the guts of larvae, pupae and newly emerged worker honey bees are sterile. The normal gut microflora develops sometime after emergence of the adult. The caged bees had access only to test diets throughout the investigation and thus symbionts could not be readily acquired. 
The nurse bees were not able to rear brood in the preliminary portion of the experiment, with the exception of those in cages 2,4 and 8 in which an average of only 23 larvae were reared to the sealed brood stage. The subsequent brood count revealed that an average of only one sealed brood cell was present in these three cages. One of the reasons for the inability of nurse bees to rear brood was that not enough diet was being consumed for brood rearing during the preceding brood count period. The decline in diet intake was due to the presence of sugar syrup which was consumed in large quantities by the bees. Since the bees would not eat their diets, brood rearing was not possible because of a nutritional imbalance.

To alleviate this problem, daily sugar syrup feedings were discontinued. Thus, when bees were forced to eat the diet on an eat-or-starve basis, they ate their artificial diet and started to rear brood (Table 2).

Another reason for the bees not eating enough of their diet was the physical inadequacy of it during the first month of the experiment. This problem was solved by changing the consistency of the diet. The modification involved a change in the concentrations of invert sugar and powdered sugar until a satisfactory mixture of the diet was obtained. Once nurse bees began eating the diet, they were then able to rear brood. These results indicate that even if caged bees are deprived of the proper nutrients for brood rearing for a period of time, they will be able to rear brood if they are fed a proper diet subsequently.

Insects accumulate stores of nutrients in their body tissues to be mobilized and later used for nutritional purposes (House, 1972). This phenomenon apparently occurred because in the beginning of the experiment, bees in all cages started rearing brood but only bees in three cages-2, 4 and 8 were able to rear larvae to the sealed brood stage (Table 2). Subsequently, even these bees could not continue brood rearing since the nurse bees were not receiving the proper balance of nutrients due to insufficient diet intake. When the improper diet was modified to an adequate one, the bees were able to rear three cycles of brood. It was shown by HAYDAK (1937) that when protein-starved bees are offered pollen, normal development is re-established and the young bees reared by them are normal. Also, there is a possible relationship between pyridoxine and longevity of adult bees as suggested by Seriay-BACK (1961).

When the first recordings were made on June 14, two days before the initiation of the experiment, enough diet was being consumed for the bees to rear brood. Bees in all 12 cages, in fact, reared brood at this time, but then brood rearing began to decrease rapidly. When daily feeding of sugar syrup was terminated on day 19 , diet consumption went up immediately resulting in an initiation of brood rearing by bees in cages 1-10. Sugar syrup was 
offered to the bees on two other days : 33 and 50 . On both occasions, there was a pronounced reduction in the amount of diet consumed by the bees (Figures 1 and 2).

The mortality of the caged bees was much higher than the number of bees reared during the experiment. Consequently, brood production declined due to aging and related physiological changes in the nurse bees. HAYDAK (1963) reported that nurse bees can rear brood for a considerable period of time, however, the number of sealed cells produced is rather small. Older nurse bees are not as efficient as normal nurses in queen rearing (HAYDAK et al., 1964). Also, there is a considerable decrease in the vitamin content of larval food secreted by older bees (HAYDAK, 1961b).

Table 3 shows that good results are obtained with Diet D. The average amount of diet $\mathrm{D}$ consumed during the three brood count periods by these adult bees in rearing one larva to the sealed brood stage was $670 \mathrm{mg}$ or $134 \mathrm{mg}$ of casein. The amount of pyridoxine can be calculated by averaging the amounts consumed during the brood count periods (Table 3). Bees feeding on diet $D$ consumed an average of $5.4 \mu \mathrm{g}$ of pyridoxine per larvae reared to the sealed brood stage. However, the average daily food intake of an individual bee feeding on diet $D$ during the 70 day test period was $4.9 \mathrm{mg}$ (Table 4). Alfonsus (1932) reported that $144.9 \mathrm{mg}$ of pollen, which is equal to about $45 \mathrm{mg}$ of protein, was required to rear one bee. Schaefer and Farrar (1941) stated that $49 \mathrm{mg}$ of air dried soybean flour, with a protein content of 50-52\% was necessary to produce one bee. $\mathrm{W}_{\mathrm{AHL}}$ (1963), in a longevity study with caged, queenless bees, feeding on a $33 \%$ protein and honey diet, found that bees consumed an average of $13.2 \mathrm{mg}$ of pollen, or $6.6 \mathrm{mg}$ of soybean flour, or $4.0 \mathrm{mg}$ of yeast per day. These investigations clearly illustrate that there is a considerable amount of variation in the amount of food consumed not only in caged, queenless bees, but also in brood rearing honey bees. The validity of a comparison of the amount of food required to produce one bee between the present data and those of the other investigators is perhaps open to question due to differences in the genetic stock of the bees used, time of the year that the experiment was conducted, climate and related factors.

Statistically there is no difference in the number of larvae reared per gram of diet consumed between the bees feeding on diets $A$ and $D$ at the 5 percent level (Table 5), which indicates that diet $\mathrm{D}$ contained an adequate amount of pyridoxine in order for the nurse bees to rear brood. Table 5 also shows there is no difference at the 5 percent level between the bees feeding on diets $\mathrm{B}, \mathrm{C}, \mathrm{D}$ and $\mathrm{E}$ in terms of the number of larvae reared for each gram of diet consumed. An increase in the amount of vitamin $B_{6}$ did not increase the number of larvae reared. Therefore, the optimum concentration of the vitamin pyridoxine for brood rearing lies between diet E ( $2 \mathrm{mg}$ per 500 grams 
of diet) and diet $\mathrm{D}(4 \mathrm{mg}$ per 500 grams of diet). The bees feeding on diet $\mathrm{F}$, which contained no pyridoxine, could not rear brood.

All adult bees during period II were able to rear an average of 1.19 larvae to the sealed brood stage per gram of diet consumed (Table 5). The average number of larvae reared during periods $I$ and III were $(0.82)$ and $(1.10)$ respectively. The differences in brood production between the brood count periods may be explained on the basis that initially the bees were not feeding on enough diet to receive a sufficient amount of nutrients to rear brood. Also, the bees may have depleted their store of vitamins and did not completely recover during period $I$.

The adult bees which fed on diet $D$ were able to rear the largest average number of larvae to the sealed brood stage per adult bee, followed by diets $A, B, C, E$ and $F$. At the .05 level of significance diet $A$ was equal to diets $B$ and $D$, and $\operatorname{diet} B$ was equal to $\operatorname{diets} C$ and $E$ (Table 6). It is evident that the nutrients acquired during brood count period $I$ are expressed in the increased brood production during period II. However the increased brood production of period II could not be sustained in period III due to aging of the nurse bees and possibly other related physiological factors.

A greater similarity among the experimental diets was found when comparing the average amount (in $\mathrm{mg}$ ) of the various diets consumed per adult bee in the 10 day brood count periods (Table 7). No statistical differences were found at the 5 percent level between $\operatorname{diets} A, B, C$ and $E$ or between $\operatorname{diets} A, B, C$ and $D$. The bees feeding on diet $F$ consumed a considerably smaller amount of diet per adult bee.

The results of our investigation clearly show that the vitamin pyridoxine is essential in the development of larval honey bees. The proper amount of pyridoxine required by nurse bees for brood rearing was ascertained to be in Diet $\mathrm{D}$ which contained $4 \mathrm{mg}$ of pyridoxine per 500 grams of artificial diet. Additional vitamins did not appreciably increase the ability of nurse bees to rear brood.

Reçu pour publication en novembre 1975.

Eingegangen im November 1975

\section{RÉSUMÉ}

LES BESOINS DE L'ABEILLE (Apis mellifica $\mathrm{L}$.) EN PYRIDOXINE POUR L'ÉLEVAGE DU COUVAIN

Le présent travail vise à déterminer les besoins quantitatifs en vitamine $B$, pyridoxine, nécessaires à l'élevage du couvain par des abeilles en cage. On a testé 6 régimes, ne différant les uns des autres que par la quantité de pyridoxine, sur de petites colonies d'abeilles maintenues dans des chambres de vol spacieuses. De cette façon on a déterminé la quantité de nourriture nécessaire aux abeilles adultes pour élever du couvain. 
Les figures 1 et 2 donnent la quantité moyenne de nourriture (mg) prélevée par les abeilles sur les différents régimes. La consommation a rapidement diminué au cours de la première partie de l'expérience en raison d'une mauvaise pondération des divers constituants. Lorsqu'on leur a fourni un régime artificiel approprié, les abeilles ont été capables de se nourrir et d'élever du couvain.

Le tableau 1 donne la liste des constituants, et leurs proportions, entrant dans la composition du régime artificiel utilisé à base de candi. La concentration en pyridoxine $(\mathrm{mg} / 500 \mathrm{~g})$ dans les six régimes testés (A-F) est la suivante : A-10, B-8, C-6, D-4, E-2 et F-0. On a testé sur 2 colonies différentes chaque concentration de vitamine.

Le tableau 2 indique le nombre de cellules de couvain auxquelles les abeilles, nourries avec les divers régimes, ont apporté leurs soins. On a observé très peu de couvain au cours des comptages préliminaires en raison de la consommation d'une nourriture non appropriée. Dès qu'elles se mettent à consommer des quantités suffisantes de nourriture, les abeilles sont toutes capables d'élever du couvain, sauf celles nourries avec le régime $F$ qui ne contient pas de pyridoxine. Le régime $\mathrm{D}$, qui contient $4 \mathrm{mg}$ de pyridoxine, suffit pour obtenir un élevage de couvain.

Le tableau 3 illustre la quantité moyenne des divers régimes (g) et de pyridoxine ( $\mu g$ ) consommée par les abeilles en cage pour élever une larve jusqu'au stade de couvain operculé. Ce tableau donne également le nombre d'abeilles présentes dans chaque cage. La prise de nourriture journalière moyenne des abeilles adultes est présentée dans le tableau 4 . Les plus fortes quantités de nourriture ont été prélevées entre les $21^{\mathrm{e}}$ et $50^{\mathrm{e}}$ jours, lorsque les nourrices des régimes $A, B, C, D$, et $E$ élevaient activement du couvain. Les abeilles nourries avec le régime $F$ ont consommé la plus petite quantité de régime et n'ont pu élever de couvain.

Le tableau 5 donne le nombre moyen de larves élevées jusqu'au stade de couvain operculé par gramme de régime consommé par les abeilles en cage. Puisque les régimes A et $D$ ne sont pas significativement différents, c'est donc que le régime $D$ renferme des quantités suffisantes de pyridoxine pour l'élevage de couvain. Il n'y a pourtant pas de différence à $5 \%$ près, du point de vue du nombre de larves élevées par gramme de régime consommé, entre les abeilles qui sont nourries avec les régimes $\mathrm{B}, \mathrm{C}, \mathrm{D}$ et $\mathrm{E}$. Une augmentation de la quantité de vitamine B6 par rapport à la quantité utilisée dans le régime $D$ n'a pas augmenté le nombre de larves élevées.

Le nombre moyen de larves élevées jusqu'au stade de couvain operculé par abeille est indiqué par le tableau 6. Les abeilles nourries avec le régime $D$ ont élevé jusqu'au stade de couvain operculé un nombre de larves significativement différent du nombre de larves élevées par les abeilles nourries avec les autres régimes, excepté le régime $A$.

Le tableau 7 donne pour chacun des régimes la quantité moyenne des différents régimes consommée par abeille au cours de 3 périodes de comptage du couvain. On n'a pas trouvé de différence statistique entre les régimes $\mathrm{A}, \mathrm{B}, \mathrm{C}$ et $\mathrm{E}$ ou entre les régimes $\mathrm{A}, \mathrm{B}, \mathrm{C}$ et $\mathrm{D}$. Pourtant la prise de nourriture des abeilles sur les régimes $D$ et $E$ est statistiquement différente. De plus la consommation par individu des abeilles nourries avec le régime $F$ est considérablement plus faible.

Cette étude montre également que la préparation de la nourriture appropriée est de la plus haute importance lorsqu'il s'agit d'élever des abeilles en confinement. Il ne suffit pas que la nourriture soit parfaitement mélangée de façon à assurer une bonne répartition des divers composants, il faut encore qu'elle soit suffisamment humide pour faciliter une consommation correcte. La consistance de la nourriture et la quantité de sirop offert aux abeilles déterminent la quantité de nourriture consommée; celle-ci, en retour, influence le nombre de larves susceptibles d'être élevées. La prise de nourriture donne l'indication directe de la quantité de vitamines et des autres substances nutritives ingérées par les abeilles.

Les résultats confirment le travail fait par les précédents chercheurs, selon lesquels la présence de pyridoxine est nécessaire dans l'alimentation des larves d'abeille. Le régime $D$ qui 
renferme $4 \mathrm{mg}$ de pyridoxine pour $500 \mathrm{~g}$ convient au développement larvaire. La consommation journalière moyenne des abeilles nourries avec le régime $D$ a été de $4,9 \mathrm{mg} / \mathrm{abeille}$. L'élevage d'une larve jusqu'au stade de couvain operculé a nécessité la consommation de $670 \mathrm{mg}$ de régime $D$, qui renfermait $134 \mathrm{mg}$ de caséine et $5,4 \mu \mathrm{g}$ de pyridoxine, par environ 1085 abeilles adultes en cage $(0,62 \mathrm{mg}$ de régime/abeille) durant 3 élevages de larves.

\section{ZUSAMMENFASSUNG}

\section{DER PYRIDOXIN-BEDARF DER HONIGBIENE (Apis mellifica L.) BEI DER BRUTAUFzUCHT}

Ziel der vorliegenden Arbeit war die quantitative Bestimmung des Bedarfs an Pyridoxin (Vitamin $B_{6}$ ) gekä figter Honigbienen bei der Brutaufzucht. Insgesamt wurden sechs verschiedene Nahrungsangebote getestet, die sich nur in ihrem Pyridoxingehalt unterschieden. Dazu wurden Versuchsvölkchen in grossen Flugkäfigen gehalten. Die zur Brutaufzucht notwendige Nahrungsmenge der erwachsenen Bienen wurde ebenfalls bestimmt.

Abbildung 1 und 2 zeigen die durchschnittliche Nahrungsmenge in Milligramm, die von den Bienen bei der jeweiligen Diät verzehrt wurde. Infolge eines ungeeigneten Verhältnisses der verschiedenen Komponenten nahm der Nahrungsverzehr während der Voruntersuchung rasch ab. Bei Verabreichung einer angemessenen künstlichen Diät waren die Bienen imstande, Brut zu ernähren und aufzuziehen. 51 - 70 Tage alte Bienen waren jedoch bei keiner Diät fähig, Brut aufzuziehen.

Die Bestandteile und Mengen der Zusammensetzung der künstlichen Zuckerteignahrung sind aus Tabelle 1 ersichtlich. Die Pyridoxinkonzentration $(\mathrm{mg} / 500 \mathrm{~g})$ der sechs verschiedenen Versuchs-Nahrungsangebote ( $A-F$ ) betrug für $A=10, B=8, C=6, D=4, E=2, F=0$. Jede Vitaminkonzentration wurde in zwei verschiedenen Völkchen getestet.

Tabelle 2 zeigt die Zahl der Brutzellen, die bei der jeweiligen Diät von den Pflegebienen gepflegt wurden. Als Folge ungenügender Futteraufnahme wurde bei den Zählungen in den Vorversuchen nur sehr wenig Brut festgestellt. Sobald die Ammenbienen angemessene Nahrungsmengen zu sich nahmen, war die Brutaufzucht bei allen Bienen, mit Ausnahme derer, die Diät F (ohne Pyridoxin) erhielten, möglich. Diät D mit $4 \mathrm{mg}$ Pyridoxin war ausreichend für die Brutaufzucht.

Der durchschnittliche Verzehr der verschiedenen Nahrung (g) und an Pyridoxin $(\mu g)$ der gekäfigten, erwachsenen Bienen bei der Aufzucht einer Made bis zur Verdeckelung ist in Tabelle 3 dargestellt. Diese Tabelle gibt auch die Anzahl der in jedem Versuchskäfig vorhandenen Bienen an.

Tabelle 4 gibt die durchschnittliche tägliche Nahrungsaufnahme der erwachsenen Bienen an. Zwischen dem 21. und 50. Tag, wo das Brutgeschäft der auf Diät A, B, C, D und E gesetzten Bienen besonders lebhaft war, war auch die Nahrungsaufnahme am grössten. Die auf Diät $F$ gesetzten Bienen verzehrten die geringsten Mengen und konnten keine Brut aufziehen.

Tabelle 5 zeigt die Durchschnittszahlen der von den gekäfigten Bienen bis zur Verdeckelung aufgezogenen Maden je Gramm verzehrter Nahrung. Da Diät A und D sich nicht wesentlich unterschieden, scheint es, dass Diät $D$ genügende Mengen an Pyridoxin für die Brutaufzucht enthielt. Bei $5 \%$ besteht jedoch zwischen den Bienen, die die Diät B, C, D und E aufnahmen, kein Unterschied in bezug auf die Anzahl aufgezogener Maden je Gramm verzehrter Nahrung. Eine Zunahme an Vitamin $B_{6}$ in Diät $D$ liess die Anzahl der aufgezogenen Maden nicht anwachsen. 
In Tabelle 6 ist der Durchschnitt der von einer Einzelbiene bis zur Verdeckelung aufgezogenen Maden dargestellt. Die Zahl der von einer Einzelbiene bei Diät D bis zur Verdeckelung aufgezogenen Maden unterschied sich deutlich von der der Bienen mit anderer Diät, ausgenommen Diät A.

In Tabelle 7 finden wir den durchschnittlichen Verzehr der jeweiligen Nahrung je erwachsene Biene während dreier Brutzählperioden. Statistische Unterschiede zwischen Diät A, B, C und $E$ oder zwischen $A, B, C$ und $D$ wurden nicht festgestellt. Es gibt jedoch einen deutlichen Unterschied in der Nahrungsaufnahme erwachsener Bienen bei Diät D und E. Auf Diät F gesetzte Bienen verzehrten beträchtlich kleinere Mengen.

Die Ergebnisse dieser Untersuchungen zeigen auch, dass die richtige Zubereitung der Nahrung äusserst wichtig für die Brutaufzucht gekäfigter Bienen ist. Die Nahrung muss nicht nur sorgfältig gemischt werden, um die gleichmässige Verteilung aller Komponenten zu gewährleisten, sie muss auch genügend Feuchtigkeit besitzen, um eine angemessene Aufnahme sicherzustellen. Die Konsistenz der Nahrung und die Menge an Zuckersirup, die den Bienen zur Verfügung steht, bestimmen die Menge der Nahrung, die die Bienen verzehren, und das wiederum beeinflusst die Anzahl der Maden, die aufgezogen werden können. Die Nahrungsaufnahme ist ein direkter Anzeiger für die Vitaminmengen und die anderen Mikrowirkstoffe, die von den Bienen verzehrt werden.

Unsere Befunde stützen frühere Ergebnisse anderer Forscher, die besagen, dass Pyridoxin im Bienenmadenfutter notwendig ist. Diät $\mathrm{D}$, die $4 \mathrm{mg}$ Pyridoxin in $500 \mathrm{~g}$ künstlicher Nahrung enthält, entspricht den Erfordernissen der Larvalentwicklung. Der Gesamtdurchschnitt der täglichen Nahrungsaufnahme erwachsener Bienen, die auf Diät D gesetzt waren, betrug $4,9 \mathrm{mg}$ je Biene. Um eine Made bis zur Verdeckelung aufzuziehen, wurden jedoch $670 \mathrm{mg}$ der Diät $\mathrm{D}$, die $134 \mathrm{mg}$ Kasein und 5,4 $\mu \mathrm{g}$ Pyridoxin enthielt, von durchschnittlich 1085 gekä figten erwachsenen Bienen während dreier Aufzuchten verzehrt; das sind $0,62 \mathrm{mg}$ Nahrung je Biene.

Reçu pour publication en novembre 1975.

Eingegangen im November 1975.

\section{REFERENCES}

Aepplen C. W., 1922. Tremendous growth force. Glean. Bee Cult. 50, 151-3.

Alfonsus E. O., 1932. Zum Pollenverbrauch des Bienenvolkes. Arch. Bienenk. 14, 220-3.

BACK E., 1956. Einfluss der im Pollen enthaltenen Vitamine auf Lebensdauer, Ausbildung der Pharynxdrüsen und Brutfähigkeit der Honigbiene. Insectes Sociaux, 3, 285-92.

DAdD R. H., 1973. Insect nutrition : current development and metabolic implications. Ann. Rev. Entomol. 18, 381-420.

Dalgliesh C. E., 1951. Biological degradation of tryptophan. Quart. Rev. Chem. Soc., 5, 227-44.

De Groot A. P., 1953. Protein and amino acid requirements of the honeybee (Apis mellifica L.). Physiol. Comp. et Oecolog., 3, fasc. 2 and 3, 90 p.

Dietz A. and HaYdak M. H., 1965. Causes of nutrient deficiency in stored pollen for the development of newly emerged honey bees. Proc. Int. Apicult. Congr., 20, 238-41.

DiETz A., 1969. Initiation of pollen consumption and pollen movement through the alimentary canal of newly emerged honey bees. Ann. Ent. Soc. Am., 62, 43-6.

Dutcher R. A., 1918. Vitamin studies. III. Observation on the curative properties of honey, nectar and corn pollen in avian polyneuritis. Jour. Biol. Chem., 36, 551-5.

Gilliam M., 1971. Microbial sterility of the intestinal content of the immature honey bee. Ann. Ent. Soc. Am., 64, 315-6.

HANSER G., 1971. Quantitative Untersuchungen über das Vorkommen von Vitamin $B_{6}$ bei den drei Kasten der Honigbiene, Apis mellifera. Z. Naturforsch. Teil B 26, 956-61. 
HAYDAK M. H., 1935. Brood rearing by honey bees confined to a pure carbohydrate diet. J. Econ. Ent., 28, 647-60.

HAYDAK M. H., 1937. The influence of pure carbohydrate diet on newly emerged honey bees. Ann. Ent. Soc. Amer., 30, 258-62.

HAYDAK M. H., 1949. Causes of deficiency of soybean flour as a pollen substitute for honey bees. J. Econ. Ent., 42, 573-9.

HAYDAK M. H., 1960. Vitamin content of royal jelly from honey bee colonies fed normal diet and from those fed pollen substitutes. Ann. Ent. Soc. Am., 53, 695.

HAYDAK M. H., 196la. Influence of storage on the nutritive value of pollen for newly emerged bees. Am. Bee J. 101 (9), 354-5.

HAYDAK M. H., 1961b. The changes in the vitamin content of royal jelly produced by nurse bees of various ages in confinement. Bee World 42, 57-9.

HaYDak M. H., 1963. Age of nurse bees and brood rearing. J. Apic. Res., 2, 101-3.

Haydak M. H., 1970. Honey bee nutrition. Ann. Rev. Ent., 15, 143-56.

HAYDAK M. H. and Vivino A. E., 1943. Changes in vitamin content during the life of the worker honey bee. Arch. Biochem., 2, 201-7.

HAYdak M. H., PAtel N. G. and Dietz, A. 1964. Queen rearing and the age of nurse bees. Ann. Ent. Soc. Am., 57, 262-3.

HAYDAK M. H. and DieTz, A. 1965. Influence of the diet on the development and brood rearing of honey bees. Proc. Int. Apicult. Congr., 20, 158-61.

Haydak M. H. and Dietz, A. 1972. Cholesterol, pantothenic acid, pyridoxine and thiamine requirements of honey bees for brood rearing. J. Apic. Res., 11, 105-9.

House H. L., 1972. Insect Nutrition. In : Fiennes R. A., Biology of Nutrition. Pergamon Press, New York, p. 513-73.

Juritza G., 1969. Der Vitaminbedarf normaler und aposymbiontischer Lasioderma serricorne F. und die Bedeutung der symbiontischen Pilze als Vitaminquelle für ihre Wirte. Oecologia, Berlin, 3, 70-83.

Kitzes G., Schuette H. A. and ElvehJem C. A., 1943. The B vitamins in honey. $J$. Nutr., 26, 241-50.

Koch A. and Schwarz I., 1956. Wirkstoffe der B-Gruppe in der Bienennahrung. Insectes Sociaux 3, 213-28.

Maurizio A., 1954. Pollenernährung und Lebensvorgänge bei der Honigbiene (Apis mellifica L.). Landwirtsch. Jahrb. Schweiz., 68, 115-82.

Nelson E. V., Roberts R. B. and Stephens W. P., 1972. Rearing larvae of the leaf-cutter bee Megachile rotundata on artificial diets. J. Apic. Res., 11, 153-6.

Pinamonti S., Petris A. and Miliani M., 1970. Studies on the kynurenine transaminase of Schistocerca gregaria Forsk. (Orthoptera, Acrididae). Comp. Biochem. Physiol., 37, 311-20.

SANG J. H., 1962. Relationship between protein supplies and B vitamin requirement in axenically cultured Drosophila. J. Nut., 77, 355-68.

Schaffer $C$. W. and Farrar C. L., 1941. The use of pollen traps and pollen supplements in developing honey bee colonies. Circ. U. S. Dept. Agr. E-531.

Serian-Back E., 1961. Vitamine - wichtige Faktoren in der Bienenernährung. Z. Bienenforsch. 5, 234-7.

Sundaram T. K. and Sarma P. S., 1953. Tryptophane metabolism in the rice moth larva (Corcyra aphalonica). Nature 172, 627-8.

WAHL O. and Back E., 1955. Einfluss der im Pollen enthaltenen Vitamine auf Lebensdauer, Ausbildung der Pharynxdrüsen und Brutfähigkeit der Honigbiene (Apis mellifica L.). Naturwissensch, 42, 103-4.

W AHL O., 1963. Vergleichende Untersuchungen über den Nährwert von Pollen, Hefe, Sojamehl and Trockenmilch für die Honigbiene. Z. Bienenforsch. 6, 209-80.

Weaver N., 1964. A pollen substitute for honey bee colonies. Glean. Bee Cull., 92 (9), 550-3. 